Original Article

\title{
Perilaku Pencegahan Demam Berdarah Dengue Masyarakat Pesisir
}

\section{Behavior Prevention of Dengue Hemorrhagic Fever in Coastal Communities}

\author{
Sulidah*, Ana Damayanti, Paridah \\ Fakultas Ilmu Kesehatan, Universitas Borneo Tarakan \\ (*sulidah06@gmail.com)
}

\begin{abstract}
ABSTRAK
Penelitian ini bertujuan untuk mengidentifikasi perilaku pencegahan DBD oleh masyarakat pesisir. Metode penelitian berupa penelitian kuantitatif dengan pendekatan cross sectional. Populasi penelitian adalah seluruh keluarga di lokasi penelitian yaitu di Tanjung Pasir dan Tanjung Batu yang merupakan wilayah pesisir. Besar populasi $442 \mathrm{KK}$ dengan jumlah jiwa 1.803 orang. Besar sampel $210 \mathrm{KK}$ yang diambil dengan teknik stratified random sampling. Pengumpulan data menggunakan kuesioner tertutup dengan Cronbach Alpha 0,81. Dari hasil penelitian teridentifikasi 70\% masyarakat melakukan pengurasan dengan frekuensi kurang dari semestinya; cara menguras tidak tepat dilakukan oleh 77,6\%; sebanyak $41,4 \%$ tidak pernah menutup tempat penampungan air dan 34,3\% menutup hanya kadangkadang; 86,7\% tidak pernah mengubur benda bekas dan 55,2\% melakukan pembuangan sampah yang tidak baik; sebanyak 63,3\% memiliki kebiasaan menggantung baju bekas pakai diluar lemari pakaian; dan $83,8 \%$ tidak melakukan abatesasi. Perilaku PSN tidak baik dilakukan oleh $61 \%$ masyarakat dan $39 \%$ yang memiliki perilaku PSN baik. Analisis uji Somers'd diperoleh p $<0,05$ membuktikan ada hubungan yang bermakna antara perilaku PSN dengan pencegahan DBD. Disarankan pemerintah untuk meningkatkan pemberian pendidikan kesehatan agar pengetahuan dan kesadaran masyarakat dalam pencegahan penularan DBD karena tendahnya perilaku pencegahan DBD masyarakat pesisir.
\end{abstract}

\section{Kata kunci: DBD, Perilaku pencegahan, Masyarakat Pesisir}

\begin{abstract}
This study aims to identify its prevention behavior by coastal communities. The research method is quantitative with a cross-sectional approach. The population in this study were all families in the study area as many as 442 households with 1,803 people in the coastal area of Tanjung Pasir and Tanjung Batu. The sample size was 210 households were taken by using a stratified random sampling technique. Data collection used a closed questionnaire with Cronbach Alpha 0.81. From this research, it was identified that $70 \%$ of the community carried out draining with less than proper frequency; inappropriate drainage method was performed by $77.6 \% ; 41.4 \%$ never closed water reservoirs and $34.3 \%$ closed occasionally; $86.7 \%$ never bury used objects and $55.2 \%$ do bad garbage disposal; $63.3 \%$ have the habit of hanging used clothes outside the wardrobe, and $83.8 \%$ did not do abatization. $61 \%$ of the public had bad eradicating mosquito nests behavior and $39 \%$ had good eradicating mosquito nests behavior. The Somers'd test analysis obtained $\mathrm{p}<0.05$ proving that there was a significant relationship between eradicating mosquito nests behavior and the prevention of DHF. It is recommended to the government to increase the provision of health education towards public knowledge and awareness in preventing DHF transmission is due to the low DHF prevention behavior in coastal communities.
\end{abstract}

Key words: DHF, Preventive Behavior, Coastal Communities

https://doi.org/10.33860/jik.v15i1.355

(C) 2021 by the authors. Submitted for possible open access publication under the terms and conditions of the Creative

Commons Attribution (CC BY SA) license (https://creativecommons.org/licenses/by-sa/4.0/). 


\section{PENDAHULUAN}

Kota Tarakan merupakan daerah endemis DBD dimana kasus terus terjadi setiap tahun diberbagai wilayah di Kota Tarakan. Sebagai sebuah kota pulau, Tarakan di kelilingi oleh garis pantai sehingga sebagian besar wilayahnya merupakan daerah pesisir. Sayangnya belum ada kajian yang menjelaskan tentang persamaan atau perbedaan kejadian DBD antara wilayah pesisir dan daratan. Hasil studi pendahuluan tentang kondisi lingkungan yang dilakukan melalui observasi pada sebagian besar wilayah pesisir menunjukkan karakteristik yang seragam berupa banyaknya sampah plastik dan benda bekas lainnya yang dapat menjadi habitat nyamuk aedes aegypti. Ditemukan pula jentik nyamuk bahkan nyamuk aedes aegypti dewasa pada wilayah pemukian penduduk. Nyamuk aedes aegypti hidup dan berkembang biak pada air yang jernih, tidak mengalir, dan tidak langsung berhubungan dengan tanah.

Berdasarkan informasi Dinas Kesehatan Kota Tarakan (2019), kasus tertinggi terjadi tahun 2016 sebanyak 545 kasus, kemudian menurun kejadiannya pada tahun 2017 dan 2018 hingga di bawah 400 kasus; tetapi kembali meningkat tahun 2019 sebanyak 427 kasus. Kelurahan Mamburungan merupakan salah satu kelurahan yang mengalami kejadian DBD dengan angka cenderung stabil tinggi. Insident Rate DBD di Kelurahan Mamburungan tahun 2019 sebesar 50,6\%, lebih tinggi dibandingkan insident rate Kota Tarakan sebesar 49,3\%. Angka Bebas Jentik (ABJ) Kelurahan Mamburungan juga baru mancapai 76\%. dibawah target ABJ Kota Tarakan sebesar 90\%. Menurut Madeira et al, karakteristik lingkungan diduga turut berperan terhadap kemampuan dan daya hidup vektor, antara lain lingkungan fisik, temperatur udara, kelembaban, curah hujan, faktor angin, paparan sinar matahari, keadaan arus air, termasuk pula faktor lingkungan kimiawi dan lingkungan biologi. ${ }^{3}$

Meskipun demikian, perkembangbiakan vektor pembawa virus dengue terutama sangat dipengaruhi oleh perlaku masyarakat yang cenderung abai terhadap kebersihan dan kesehatan lingkungan. Hal inilah yang menyebabkan nyamuk aedes aegypti selalu ada dan menjadi rantai penularan virus dengue. Menurut WHO upaya memberantas sarang tempat perkembangbiakan nyamuk dan pengendalian vektor penyakit DBD merupakan upaya utama dan terpenting yang masuk dalam integrated vector manajemen. ${ }^{4}$ Kesadaran masyarakat untuk aktif berpartisipasi dalam bentuk perilaku pencegahan menjadi ujung tombak keberhasilan pengendalian penyakit DBD.

Gerakan Pemberantasan Sarang Nyamuk (PSN) digunakan sebagai strategi utama dalam program pengendalian DBD yang bertujuan memutus rantai penularan. ${ }^{5}$ Dalam program tersebut masyarakat Indonesia telah mengenal cara pencegahan DBD dengan sebutan 3M; yaitu mengubur barang bekas yang dapat menjadi tempat berkembangbiaknya nyamuk aedes aegypti, menutup tempat penampungan air, dan menguras bak penampungan air secara berkala. Gerakan PSN hanya akan berjalan secara efektif dan efisien dengan partisipasi seluruh lapisan masyarakat. Penelitian ini dilakukan di Desa Tanjung Pasir dan Tanjung Batu yang merupakan daerah pesisir di Kelurahan Mamburungan Kota Tarakan; bertujuan untuk mengidentifikasi bagaimana perilaku pencegahan DBD pada masyarakat pesisir.

\section{METODE PENELITIAN}

Penelitian ini merupakan penelitian deskriptif korelatif dengan pendekatan cross sectional. Populasi penelitian ini adalah keluarga dalam masyarakat wilayah pesisir di Kelurahan Mamburungan Kota Tarakan yang terdiri dari daerah Tanjung Pasir dan Tanjung Batu. Besar populasi sebanyak 442 kepala keluarga dengan jumlah jiwa 1.803 orang. Sampel penelitian merupakan keluarga yang memenuhi kriteria inklusi yaitu: telah tinggal di lokasi penelitian lebih dari 6 bulan, berusia lebih dari 17 tahun atau telah menikah, dan bersedia menjadi responden. Besar sampel sebanyak 210 keluarga yang diambil dengan teknik stratified random sampling.

Pengumpulan data menggunakan instrumen berbentuk kuesioner berisi pertanyaan tertutup dan terstruktur dengan Cronbach Alpha 0,81. Data dianalisa menggunakan uji korelasi Somers'd dengan tingkat kepercayaan $95 \%$.

Penelitian ini telah mendapatkan sertifikat lolos uji etik dari Komisi Etik Penelitian Kesehatan (KEPK) dengan nomor 003/KEPK-FIKES UBT/XI/2020..

\section{HASIL}


Responden penelitian ini sebanyak 116 orang $(55,2 \%)$ berjenis kelamin perempuan, lebih banyak dibandingkan laki-laki sebanyak 94 orang $(44,8 \%)$. Hal ini mengingat perempuan umumnya merupakan ibu rumah tangga yang banyak tinggal didalam rumah; sedang laki-laki sebagai kepala keluarga beraktifitas diluar rumah. Berdasarkan kelompok usia, urutan proporsi dari yang paling besar adalah responden berusia 31-45 tahun sebanyak 80 orang $(38,1 \%)$; kemudian kelompok usia 46-60 tahun sebanyak 61 orang (29\%), kelompok usia 18-30 tahun sebanyak 51 orang $(24,8 \%)$, dan kelompok usia $>60$ tahun sebanyak 17 orang $(8,1 \%)$. Data tersebut memberi indikasi bahwa responden penelitian ini pada umumnya masih dalam usia produktif (Tabel 1).

Hasil identifikasi perilaku pencegahan DBD oleh masyarakat pesisir dimuat pada tabel 2 menjelaskan perilaku pencegahan DBD yang berkaitan dengan kebiasaan menguras tempat penampungan air. Jumlah responden yang melakukan pengurasan secara berkala sebanyak 114 keluarga (54,3\%); selebihnya ada 96 keluarga $(45,7 \%)$ yang hanya melakukan pengurasan secara insidental saja. Selain rutinitas, frekuensi menguras juga menjadi indikator perilaku pencegahan yang penting. Pada penelitian ini sebagian besar responden melakukan pengurasan secara berkala dengan frekuensi 1-2 kali/bulan sebanyak 38 keluarga $(33,3 \%)$ dan frekuensi 3-4 kali/bulan sebanyak 35 keluarga $(30,7 \%)$. Sebagian kecil responden melakukan pengurasan secara berkala dengan frekuensi lebih dari 4 kali/bulan sebanyak 23 keluarga $(20,2 \%)$ dan frekuensi kurang dari 1 kali/bulan sebanyak 18 keluarga $(15,8 \%)$.

Peneliti juga menemukan 96 keluarga yang hanya melakukan pengurasan secara insidental saja, artinya keluarga tersebut melakukan pengurasan hanya jika dianggap perlu saja yaitu ketika tempat penampungan air dalam keadaan kotor atau ketika terdapat jentik dalam jumlah yang banyak. Frekuensi pengurasan yang dilakukan dalam keadaan tersebut umumnya hanya sekali dalam 1-2 bulan. Pada penelitian ini didapatkan 73 keluarga $(76 \%)$ yang melakukan pengurasan kurang dari $1 \mathrm{kali} / \mathrm{bulan}$, selebihnya melakukan pengurasan secara insidental dengan frekuensi 1-2 kali/bulan sebanyak 18 keluarga $(18,8 \%)$ dan hanya 5 keluarga $(5,2 \%)$ yang melakukan pengurasan secara insidental dengan frekuensi
3-4 kali/bulan. Berdasarkan cara menguras sebagian besar keluarga melakukan pengurasan dengan cara yang kurang benar yaitu sebanyak 162 keluarga $(77,1 \%)$ dan hanya terdapat 48 keluarga $(22,9 \%)$ yang melakukan pengurasan dengan cara yang benar (Tabel 2).

Pada penelitian ini sebagian besar keluarga tidak pernah menutup tempat penampungan airnya yaitu sebanyak 87 keluarga $(41,4 \%)$ dan sebanyak 71 keluarga $(33,8 \%)$ tidak rutin menutup (kadang-kadang). Kuantitas keluarga yang rutin (selalu) menutup tempat penampungan air hanya 52 keluarga $(24,8)$. Masyarakat di Desa Tanjung Pasir dan Tanjung Batu sesuai dengan tabel 3 menunjukkan responden tidak mengubur benda bekas sebanyak 182 keluarga $(86,7 \%)$ dan hanya sebagian kecil responden yang mengubur benda bekas yaitu sebanyak 28 keluarga $(13,7 \%)$.

Hanya terdapat 34 keluarga $(16,2 \%)$ yang melakukan abatesasi dan sebagian besar tidak melakukan abatesasi yaitu sebanyak 176 keluarga $(83,8 \%)$. Secara keseluruhan tampak sekali bahwa masyarakat di Desa Tanjung Pasir dan Tanjung Batu belum memiliki perilaku pencegahan DBD yang baik. Dengan demikian resiko penularan DBD ditempat tersebut sangat tinggi.

Uji somers' $d$ sebagaimana tabel 4 diatas membuktikan bahwa upaya Pemberantasan Sarang Nyamuk (PSN) berkorelasi positif terhadap pencegahan DBD dengan tingkat kemagnaan $\mathrm{p}<0,05$.

Tabel 1. Karakteristik Responden Berdasarkan Usia dan Jenis Kelamin

\begin{tabular}{cccc}
\hline \multirow{2}{*}{ Usia } & \multicolumn{2}{c}{ Jenis Kelamin } & N \\
\cline { 2 - 3 } & $\begin{array}{c}\text { Laki- } \\
\text { laki }\end{array}$ & Perempuan & \\
\hline $18-30$ tahun & 19 & 33 & 52 \\
$31-45$ tahun & 41 & 39 & 80 \\
$46-60$ tahun & 28 & 33 & 61 \\
$>60$ tahun & 6 & 11 & 17 \\
\hline Total & 94 & 116 & 210 \\
\hline
\end{tabular}


Tabel 2. Distribusi Responden berdasarkan Perilaku Menguras Tempat Penampungan Air

\begin{tabular}{lcc}
\hline \multicolumn{1}{c}{ Frekuensi menguras } & Berkala & Insidental \\
\hline$>4$ kali/bulan & 23 & 0 \\
3-4 kali/bulan & 35 & 5 \\
1-2 kali/bulan & 38 & 18 \\
$<1$ kali/bulan & 18 & 73 \\
\hline Cara Menguras & Berkala & Insidental \\
\hline Benar & 48 & 0 \\
Kurang benar & 66 & 96 \\
\hline
\end{tabular}

Tabel 3. Distribusi Responden Berdasarkan Perilaku Menutup Tempat Penampungan Air, Abatesasi, dan Mengubur Barang Bekas

\begin{tabular}{|c|c|c|c|c|}
\hline \multirow{2}{*}{ Menutup penampungan air } & \multicolumn{2}{|c|}{ Abatesasi } & \multicolumn{2}{|c|}{ Mengubur barang bekas } \\
\hline & $\mathrm{Ya}$ & Tidak & $\mathrm{Ya}$ & Tidak \\
\hline Selalu & 13 & 39 & 19 & 33 \\
\hline Kadang-kadang & 14 & 57 & 9 & 62 \\
\hline Tidak pernah & 7 & 80 & 0 & 87 \\
\hline Jumlah & 34 & 176 & 28 & 182 \\
\hline
\end{tabular}

Tabel 4. Analisis Korelasi Somers'd

\begin{tabular}{lccc}
\hline \multicolumn{1}{c}{ Variabel } & Value & Std. Error & Sig. \\
\hline Menguras \& Pencegahan DBD & 0,527 & 0,055 & 0,000 \\
Frek. Kuras \& Pencegahan DBD & 0,454 & 0,052 & 0,000 \\
Cara kuras \& Pencegahan DBD & 0,390 & 0,063 & 0,000 \\
Menutup bak \& Pencegahan DBD & 0,405 & 0,056 & 0,000 \\
Mengubur \& Pencegahan DBD & 0,299 & 0,060 & 0,000 \\
Buang sampah \& Pencegahan DBD & 0,486 & 0,055 & 0,000 \\
Gantung baju \& Pencegahan DBD & 0,429 & 0,060 & 0,000 \\
Obat nyamuk \& Pencegahan DBD & 0,558 & 0,059 & 0,000 \\
Abatesasi \& Pencegahan DBD & 0,218 & 0,066 & 0,002 \\
\hline
\end{tabular}

\section{PEMBAHASAN}

Demam Berdarah Dengue merupakan penyakit infeksi virus yang dapat sembuh sendiri pada sebagian besar kasus dengan insiden pada laki-laki dua kali lebih banyak dibandingkan perempuan. ${ }^{6}$ Wilayah pesisir memiliki karakteristik yang berbeda dari daratan berdasarkan ketinggian tempat diatas permukaan laut, jenis sampah, pekerjaan masyarakat, dan karakteristik kependudukan lainnya. Sebagai wilayah yang berada dekat dengan garis pantai maka wilayah pesisir memiliki ketinggian yang paling rendah diatas atas permukaan laut. Ketinggian suatu tempat berkorelasi dengan suhu dan kelembaban yang merupakan faktor penting yang mempengaruhi daya hidup dan perkembangbiakan nyamuk aedes aegypti. Lozano-Fuentes menyatakan bahwa kepadatan nyamuk aedes aegypti berkorelasi dengan parameter cuaca, indeks suhu dan kelembaban. Semakin rendah letak suatu tempat maka suhu dan kelembaban akan semakin tinggi; tetapi hal tersebut bukan merupakan suatu yang mutlak karena suhu dan kelembaban juga dipengaruhi faktor lainnya seperti kepadatan tumbuhan dan curah hujan. ${ }^{7}$ Penelitian Hendri et al membuktikan bahwa ketinggian tempat mempunyai korelasi dengan suhu di dalam dan di luar ruangan dengan arah korelasi negatif tetapi tidak ada hubungan yang signifikan dengan kelembaban di dalam dan di luar rungan. ${ }^{1}$ Sayangnya sampai saat ini informasi tentang vektor nyamuk aedes aegypti berdasarkan ketinggian tempat di Kelurahan Mamburungan sebagai lokasi penelitian dan kelurahan lain di Kota Tarakan belum tersedia. Meskipun demikian kasus DBD telah dilaporkan oleh setiap kelurahan yang membuktikan keberadaan nyamuk aedes aegypti tanpa membedakan ketinggian tempat. Nyamuk aedes aegypti memang mampu hidup dan berkembangbiak pada ketinggian di bawah $1000 \mathrm{mdpl}^{8}$

Tempat ideal bagi nyamuk tersebut umumnya berupa tempat penampungan air dan benda bekas lainnya di dalam ruangan yang berisi air bersih maupun di luar ruangan yang digenangi air. ${ }^{9}$ Survey kepadatan populasi 
jentik nyamuk aedes aegypti yang dilakukan oleh Athaillah et al. menunjukkan bahwa daerah pesisir memiliki populasi jentik berada pada kategori sedang dengan bretau index sebesar 34\% ${ }^{10}$ Pemukiman penduduk didaerah pesisir seperti di Desa Tanjung Pasir dan Tanjung Batu banyak ditemukan benda bekas tergenang air hujan yang menjadi sarang nyamuk aedes aegypti dan aedes albopictus.

Perilaku PSN pada masyarakat pesisir yang teridentifikasi pada penelitian ini masih kurang mendukung pencegahan DBD. Hal ini terbukti dengan sebagian besar masyakat melakukan pengurasan tempat penampungan air dengan frekuensi hanya 1-2 kali sebulan dengan cara menguras yang kurang benar, umumnya tidak menutup tempat penampungan air dan tidak mengubur benda bekas yang berpotensi menjadi habitat nyamuk serta sebagian besar tidak menggunakan abate sebagai upaya mencegah nyamuk bersarang pada tempat penampungan air. Perilaku lain yang menunjukkan kurang mendukung pencegahan DBD ialah kebiasaan masyarakat yang umumnya sering menggantung baju, tidak menggunakan obat anti nyamuk, dan pembuangan atau pengelolaan sampah yang tidak tepat. Kurangnya perilaku pencegahan DBD tersebut diduga menjadi penyebab utama kejadian DBD. Informasi yang dihimpun dari Puskesmas Mamburungan menunjukkan angka kejadian DBD pada lokasi penelitian dalam satu tahun terakhir sebanyak 5 kasus. Meskipun angka kejadian tersebut kecil tetapi berpotensi menjadi kejadian luar biasa jika tidak dilakukan upaya pencegahan dengan baik. Setiap masyarakat diharapkan memiliki sikap dan perilaku pencegahan yang sama baiknya dan dilakukan secara kerkesinambungan untuk dapat mencegah kejadian DBD. ${ }^{11}$

Sasaran pokok gerakan PSN dengan metode $3 \mathrm{M}$ adalah meniadakan sarang nyamuk dan mencegah telur nyamuk berkembang menjadi jentik hingga menjadi nyamuk dewasa. Siklus kehidupan nyamuk aedes aegypti mengalami metamorfosis sempurna yaitu dari telur menjadi larva, pupa dan imago. Larva nyamuk dikenal dengan sebutan jentik sedang imago merupakan nyamuk dewasa. Pertumbuhan dan perkembangan dari telur hingga menjadi nyamuk dewasa berlangsung selama 7-14 hari dan dapat lebih cepat jika berada pada suhu dan kelembaban yang sempurna. ${ }^{12}$ Sahak menyatakan bahwa kecepatan pertumbuhan dan perkembangan larva dipengaruhi oleh suhu, tempat dan keadaan air serta ketersediaan makanan dalam tempat perindukan. ${ }^{13}$ Seekor nyamuk betina dewasa mampu menghasilkan hingga lebih dari 100 butir telur yang biasanya diletakkan pada dinding wadah sedikit diatas permukaan air. ${ }^{14}$ Nyamuk betina memiliki peran penting dalam penularan virus dengue karena hanya nyamuk betina yang memiliki sifat antropofilik dan multiple feeding. Sifat antropofilik yaitu kecenderungan menghisap darah manusia; sedang sifat multiple feeding artinya kecenderungan menghisap darah beberapa kali dalam satu periode gonotropik. ${ }^{14}$

Menguras tempat penampungan air merupakan tindakan pencegahan penularan DBD yang penting berkaitan dengan habitat vektor penularnya; bukan hanya semata-mata frekuensi tetapi juga cara mengurasnya. Dalam penelitian ini korelasi antara menguras, frekuensi, dan cara menguras dengan pencegahan DBD menggunakan uji somers'd masing-masing diperoleh hubungan yang bermagna. Hasil ini sejalan dengan penelitian sebelumnya yang membuktikan bahwa frekuensi menguras tempat penampungan air berpengaruh positif dalam menghambat perkembangbiakan jentik, ${ }^{15}$ karena dengan pembersihan tempat penampungan air menyebabkan daur hidup nyamuk terputus. Dengan memperhatikan siklus hidup nyamuk, maka frekuensi pengurasan sebaiknya dilakukan sekali dalam seminggu atau sekurang-kurangnya 8-10 hari sekali. Cara menguras yang benar juga merupakan hal penting untuk diperhatikan. Telur nyamuk aedes aegypti mempunyai kemampuan bertahan dalam waktu yang lama terhadap desikasi, yaitu memampuan bertahan terhadap pengeringan bahkan hingga beberapa bulan. ${ }^{13}$ Keluarga perlu melakukan pengecekan kepadatan jentik pada tempat penampungan air secara berkala dan melakukan pengurasan jika populasi jentik telah meningkat. Sayangnya banyak keluarga yang abai dari melakukan pengecekan tersebut. Hal ini sesuai dengan temuan Zaki et al. yang menyimpulkan bahwa besar masyarakat tidak melakukan pemeriksaan jentik pada tempat penampungan air secara rutin yang dikaitkan dengan ketidaktahuan tentang penularan DBD. ${ }^{16}$ Penelitian ini telah mengidentifikasi perilaku PSN yang buruk pada masyarakat, antara lain tergambar dari ketidakteraturan dan cara 
menguras yang tidak benar. Semakin buruk perilaku PSN maka semakin banyak jentik nyamuk. ${ }^{17}$

Menutup tempat penampungan air merupakan bagian dari perilaku PSN dan menjadi alternatif jika tidak memiliki banyak kesempatan untuk melakukan pengurasan. Berdasarkan uji somers'd terbukti bahwa menutup tempat penampungan air mempunyai korelasi yang signifikan terhadap pencegahan DBD. Pemberantasan dan pencegahan DBD di arahkan pada upaya menghilangkan tempat perindukan (breeding places) nyamuk aedes aegypti ${ }^{5}$ yang antara lain dapat dilakukan dengan menutup tempat penampungan air sehingga tempat penampungan air tidak di huni oleh jentik nyamuk. Menutup tempat penampungan air mempunyai makna yang sama dengan menghilangkan tempat perindukan nyamuk. Dengan demikian semakin sedikit jumlah tempat penampungan air semakin sedikit pula tempat perindukan nyamuk. ${ }^{11}$ Larvasidasi dengan bubuk abate merupakan cara terbaik, murah, mudah dan dapat dilakukan oleh masyarakat dalam memberantas jentik aedes aegypti. ${ }^{18}$ Berkurang atau hilangnya kepadatan jentik berarti tidak memberi peluang untuk bertambahnya populasi nyamuk dewasa. ${ }^{19}$ Nyamuk dewasa dapat dibasmi dengan metode pengasapan (fogging focus), tetapi metode tersebut tidak selalu efektif membasmi nyamuk aedes aegypti terutama karena telur dan larva masih mampu berkembang menjadi nyamuk dewasa. ${ }^{20}$

Gerakan PSN dengan metode 3M harus didukung dengan perilaku sehat lainnya. Kebiasaan menggantung baju bekas pakai diluar lemari pakaian ibarat mengundang nyamuk untuk datang. Menggantung pakaian bekas pakai lebih dari satu hari berpengaruh terhadap peningkatan kepadatan jentik. $^{20}$ Kebiasaan membuang sampah sembarangan dan atau pengelolaan sampah yang tidak baik juga merupakan perilaku tidak sehat; tidak hanya beresiko terhadap kejadian DBD tetapi juga penyakit lainnya. Menurut Hastuti et al. perilaku sanitasi yang rendah dapat meningkatkan kejadian DBD. ${ }^{21}$ Pencegahan DBD harus didukung dengan perilaku membersihkan rumah dan pekarangan sekitarnya dengan tindakan yang tepat yang di dasarkan oleh pengetahuan yang baik. ${ }^{22}$ Saat ini DBD masih dianggap sebagai neglected disease oleh sebagian besar masyarakat yang membuat masyarakat tidak melakukan perilaku pencegahan yang sesuai. ${ }^{23}$ Kampanye pencegahan DBD secara masif perlu dilakukan dengan memanfaatkan berbagai media yang tersedia di masyarakat. Siddiqui et al menyarankan strategi pencegahan dan pengendalian DBD hendaknya berfokus pada peningkatan kesadaran tentang resiko penularan penyakit yang dapat dilakukan melalui media televisi sebagai sumber informasi yang sering di akses oleh masyarakat. ${ }^{24}$ Saran tersebut dirasa masih relevan untuk dilakukan, tetapi pada masa sekarang ini memanfaatkan media sosial merupakan pilihan paling tepat.

Perilaku kesehatan dalam pencegahan penyakit DBD merupakan wujud partisipasi masyarakat yang sangat penting. ${ }^{25}$ Kurangnya perilaku pencegahan memberi indikasi bahwa pemahaman masyarakat tentang DBD dan pencegahannya masih rendah. Hal ini tentu mempunyai korelasi dengan tingkat pendidikan yang juga rendah sehingga rentan dalam melakukan intervensi pencegahan penyakit. ${ }^{26}$ Terhadap kelompok masyarakat yang demikian tentu di butuhkan pendidikan kesehatan guna meningkatkan pengetahuan, kesadaran, sikap, dan perilaku positif dalam pencegahan DBD. ${ }^{27}$ Pendidikan kesehatan melalui penyuluhan kesehatan dan penyampaian informasi menggunakan berbagai media merupakan program promosi kesehatan yang rutin dilakukan. Hal ini sejalan dengan temuan Kumaran et al. yang mengidentifikasi peningkatan pengetahuan masyarakat tentang DBD tetapi perilakunya masih kurang mendukung pencegahan DBD. ${ }^{28}$ Bahkan penelitian Chandren et al. menyimpulkan bahwa perilaku kesehatan telah dimiliki oleh sebagian besar keluarga tetapi masih membutuhkan strategi agar keluarga dapat menerapkan perilakunya secara tepat sasaran. ${ }^{29}$ Seringkali perilaku pencegahan DBD hanya dilakukan secara insidental saja dan bersifat sementara. Tampaknya masyarakat membutuhkan peningkatan motivasi melalui komunikasi dan keteladanan secara terintegrasi agar perilaku pencegahan DBD dapat berlangsung secara berkesinambungan. ${ }^{30}$

Menurut Achmadi manajemen DBD berbasis wilayah adalah upaya paripurna terintegrasi antara manajemen kasus Demam Dengue sebagai sumber penularan, serta pengendalian faktor risiko penularan DBD pada 
satu wilayah RT, RW ataupun kelurahan. ${ }^{31}$ Setiap unsur dalam wilayah harus memberikan kontribusi sesuai peran masing-masing. Tenaga kesehatan bertindak sebagai edukator fasilitator; aparat pemerintahan wilayah bertugas sebagai penggerak sekaligus memberi contoh bagi masyarakat; tapi partisipasi aktif masyarakatlah yang yang menjadi penentu keberhasilannya.

\section{KESIMPULAN DAN SARAN}

Perilaku pencegahan DBD oleh masyarakat pesisir di Desa Tanjung Pasir dan Tanjung Batu masih rendah $d$ Perilaku pencegahan DBD harus bersifat permanen dan berkesinambungan. Peneliti merekomandasikan kepada pemerintah melalui Dinas Kesehatan dan puskesmas untuk memberikan pendidikan kesehatan guna meningkatkan pengetahuan dan kesadaran masyarakat dalam pencegahan penularan DBD.

\section{UCAPAN TERIMA KASIH}

Terima kasih kami ucapkan kepada Rektor dan segenap jajaran Pimpinan Universitas Borneo Tarakan yang telah menyediakan pendanaan bagi kegiatan ini. Terima kasih pula kami sampaikan kepada Lurah Mamburungan yang telah memberikan ijin kepada kami untuk melaksanakan penelitian ini, kepada Kepala Puskesmas Mamburungan yang telah menyediakan data dan informasi sehingga sangat membantu terlaksananya penelitian ini, dan juga kepada sejawat peneliti yang telah memberikan kontribusi untuk terselesaikannya penelitian ini

\section{DAFTAR PUSTAKA}

1. Madeira E, Yudiernawati A, Maemunah N. Hubungan Perilaku Hidup Bersih dan Sehat (PHBS) Ibu dengan Cara Pencegahan Demam Berdarah Dengue. Nurs News (Meriden). 2019;4(1):288-99.

2. WHO. Global Strategy For Dengue Prevention And Control 2012-2020. WHO Rep [Internet]. 2012; Available from: https://www.who.int/denguecontrol/97892415 04034/en/

3. Windaningsih N. Perilaku Masyarakat Dalam Upaya Pencegahan Penyakit Demam Berdarah ( Dbd ) Melalui Metode Pemberantasan Sarang Nyamuk. 2019;19(2).

4. Salah Debes M. Dengue Fever in Adults, a Retrospective Study. Am J Intern Med. 2016;4(6):93.
5. Lozano-Fuentes S, Hayden MH, WelshRodriguez C, Ochoa-Martinez C, Tapia-Santos $\mathrm{B}$, Kobylinski $\mathrm{KC}$, et al. The dengue virus mosquito vector Aedes aegypti at high elevation in México. Am J Trop Med Hyg. 2012;87(5):902-9.

6. Hendri J, Santya RNRE, Prasetyowati H. Distribution and Density of Dengue Hemorrhagic Fever ( DHF ) Vector Based on the Altitude in Ciamis West Java Ciamis. J Ekol Kesehat. 2015;14:17-28.

7. WHO. Comprehensive guidelines for prevention and control of dengue and dengue haemorrhagic fever [Internet]. WHO Regional Publication SEARO. 2011. 159-168 p. Available from: http://scholar.google.com/scholar?hl=en\&btn $\mathrm{G}=$ Search\&q=intitle:Comprehensive+Guideli nes+for+Prevention+and+Control+of+Dengue +and+Dengue+Haemorrhagic+Fever\#1

8. Mawardi M, Busra R. Studi Perbandingan Jenis Sumber Air Terhadap Daya Tarik Nyamuk Aedes aegypti Untuk Bertelur. J Serambi Eng. 2019;4(2):593-602.

9. Athaillah F, Ichwani R, Asmilia N. Kepadatan Larva Nyamuk Aedes spp Sebagai Vektor Penyebab Demam Berdarah Dengue ( Dbd ) Di Daerah Pesisir Alue Naga Density of Aedes aegypti as Vector Dengue Haemoragic Fever at Alue Naga Coastal e. 2018;2(4):488-92.

10. Fauziah N, Rahayu U, Thohari I. Perilaku 3M Bagi Penghuni Rumah Mempengaruhi Kejadian Penyakit Demam Berdarah Dengue. Gema Lingkung Kesehat. 2019;17(1):50-6.

11. CDC. Symptoms and Treatment [Internet]. United States: Centers for Disease Control and Prevention, National Center for Emerging and Zoonotic Infectious Diseases (NCEZID), Division of Vector-Borne Diseases (DVBD); Available from: https://www.cdc.gov/dengue/symptoms/index. html\#anchor_1555426819180

12. Sahak MN. Dengue fever as an emerging disease in Afghanistan: Epidemiology of the first reported cases. Int J Infect Dis [Internet]. 2020;99:23-7. Available from: https://doi.org/10.1016/j.ijid.2020.07.033

13. CDC. About Dengue: What You Need to Know [Internet]. United States; 2019. Available from: https://www.cdc.gov/dengue/about/index.html

14. Vannavong N, Seidu R, Stenström TA, Dada $\mathrm{N}$, Overgaard HJ. Effects of sociodemographic characteristics and household water management on Aedes aegypti production in suburban and rural villages in Laos and Thailand. Parasites and Vectors. 2017;10(1):1-14.

15. Zaki R, Roffeei SN, Hii YL, Yahya A, Appannan M, Said MA, et al. Public perception and attitude towards dengue prevention activity 
and response to dengue early warning in Malaysia. PLoS One. 2017;14(2):1-22.

16. Salawati L, Siregar ML, Hasibuan RS. Hubungan pemberantasan sarang nyamuk dengan keberadaan jentik di Kecamatan Jaya Baru Banda Aceh Tahun 2017. J Ilm Kedokt [Internet]. 2018;1(1). Available from: www.medicus-darussalam.com

17. Ningsih DP sulistiya. Evaluasi Program Kesehatan Pengendalian Penyakit Demam Berdarah Dengue (P2Dbd) Di Dinas Kesehatan Kabupaten Sleman, Yogyakarta. J Formil (Forum Ilmiah) Kesmas Respati. 2019;4(1):43.

18. Tokan PK, Sekunda MS. Analysis of the Level of Larvae Aedes Aegypty with the Risk of Transmission of Dengue Hemorrhagic Fever. 2019;4(2):76-81.

19. Saraswati K, Santjaka A. Anlisis Trend Penetasan Telur Nyamuk Aedes sp Berdasarkan Deret Waktu Di Kelurahan Teluk Kecamatan Purwokerto Selatan Kabupaten Banyumas Tahun 2017. Bul Keslingmas. 2018;37(2):171-7.

20. Muda AS, Haqi DN. Determinan Yang Berhubungan Dengan Keberadaan Jentik Di Kelurahan Rangkah Buntu, Surabaya. J PROMKES. 2019;7(1):22.

21. Hastuti NM, Dharmawan R, Indarto D. Sanitation-Related Behavior, Container Index, and Their Associations with Dengue Hemorrhagic Fever Incidence in Karanganyar, Central Java. Biol Phys Soc Environ Factors Assoc with Dengue Hemorrhagic Fever Nganjuk, East Java. 2017;02(02):174-85.

22. Xu JW, Liu H, Yaw B, Nbwi HS. The health beliefs, dengue knowledge and control behaviors among internally displaced persons versus local residents in kachin special region II, Myanmar. PLoS Negl Trop Dis [Internet]. 2020;14(6):1-14. Available from: http://dx.doi.org/10.1371/journal.pntd.000832 1

23. Leslie TE, Carson M, Coeverden E van, De Klein K, Braks M, Krumeich A. An analysis of community perceptions of mosquito-borne disease control and prevention in Sint Eustatius, Caribbean Netherlands. Glob Health Action [Internet]. 2017;10(1):1350394. Available from: https://doi.org/10.1080/16549716.2017.13503 94

24. Siddiqui TR, Ghazal S, Bibi S, Ahmed W, Sajjad SF. Use of the Health Belief Model for the Assessment of Public Knowledge and Household Preventive Practices in Karachi, Pakistan, a Dengue-Endemic City. PLoS Negl Trop Dis. 2016;10(11):1-15.

25. Meiliyana L, Damayanti R, Zakianis Z. Partisipasi Masyarakat Dalam Pencegahan Penyakit Demam Berdarah Dengue: Sebuah
Tinjauan Sistematika. Qual J Kesehat. 2020;14(1):25-37.

26. Diaz-Quijano FA, Martínez-Vega RA, Rodriguez-Morales AJ, Rojas-Calero RA, Luna-González ML, Díaz-Quijano RG. Association between the level of education and knowledge, attitudes and practices regarding dengue in the Caribbean region of Colombia. BMC Public Health. 2018;18(1):1-10.

27. Nivedita. Knowledge, attitude, behaviour and practices (KABP) of the community and resultant IEC leading to behaviour change about dengue in Jodhpur city, Rajasthan. J Vector Borne Dis. 2016;53(3):279-82.

28. Kumaran E, Doum D, Keo V, Sokha L, Sam BL, Chan V, et al. Dengue knowledge, attitudes and practices and their impact on community-based vector control in rural Cambodia. PLoS Negl Trop Dis. 2018;12(2):1-16.

29. Chandren JR, Wong LP, AbuBakar S. Practices of dengue fever prevention and the associated factors among the Orang Asli in Peninsular Malaysia. PLoS Negl Trop Dis. 2015;9(8):117.

30. Udayanga L, Gunathilaka N, Iqbal MCM, Lakmal K, Amarasinghe US, Abeyewickreme W. Comprehensive evaluation of demographic, socio-economic and other associated risk factors affecting the occurrence of dengue incidence among Colombo and Kandy Districts of Sri Lanka: A cross-sectional study. Parasites and Vectors. 2018;11(1):1-18.

31. Kemenkes. Demam Berdarah Dengue. Bul Jendela Epidemiol. 2010;2:48. 